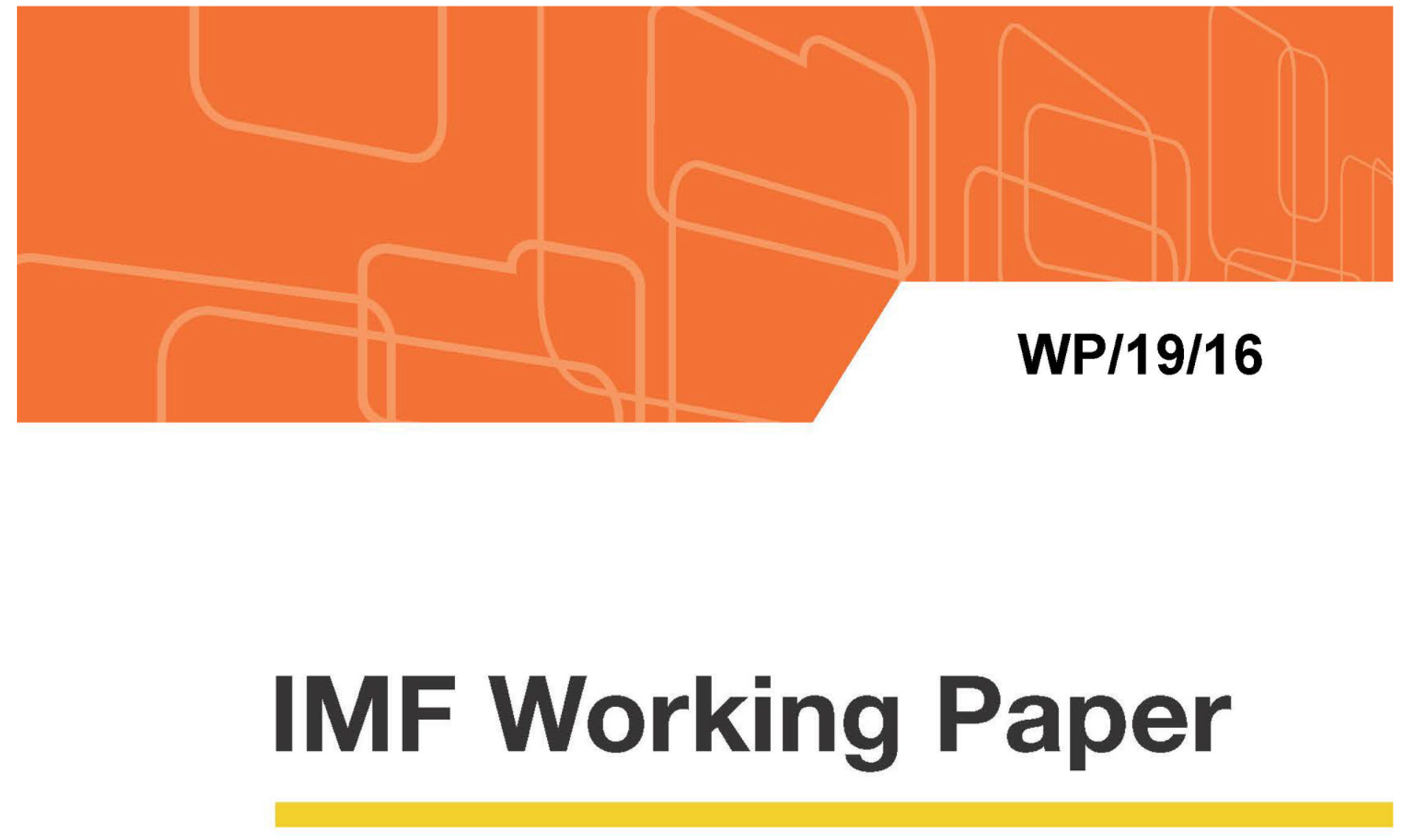

\title{
China's Digital Economy: Opportunities and Risks
}

by Longmei Zhang and Sally Chen

IMF Working Papers describe research in progress by the author(s) and are published to elicit comments and to encourage debate. The views expressed in IMF Working Papers are those of the author(s) and do not necessarily represent the views of the IMF, its Executive Board, or IMF management. 


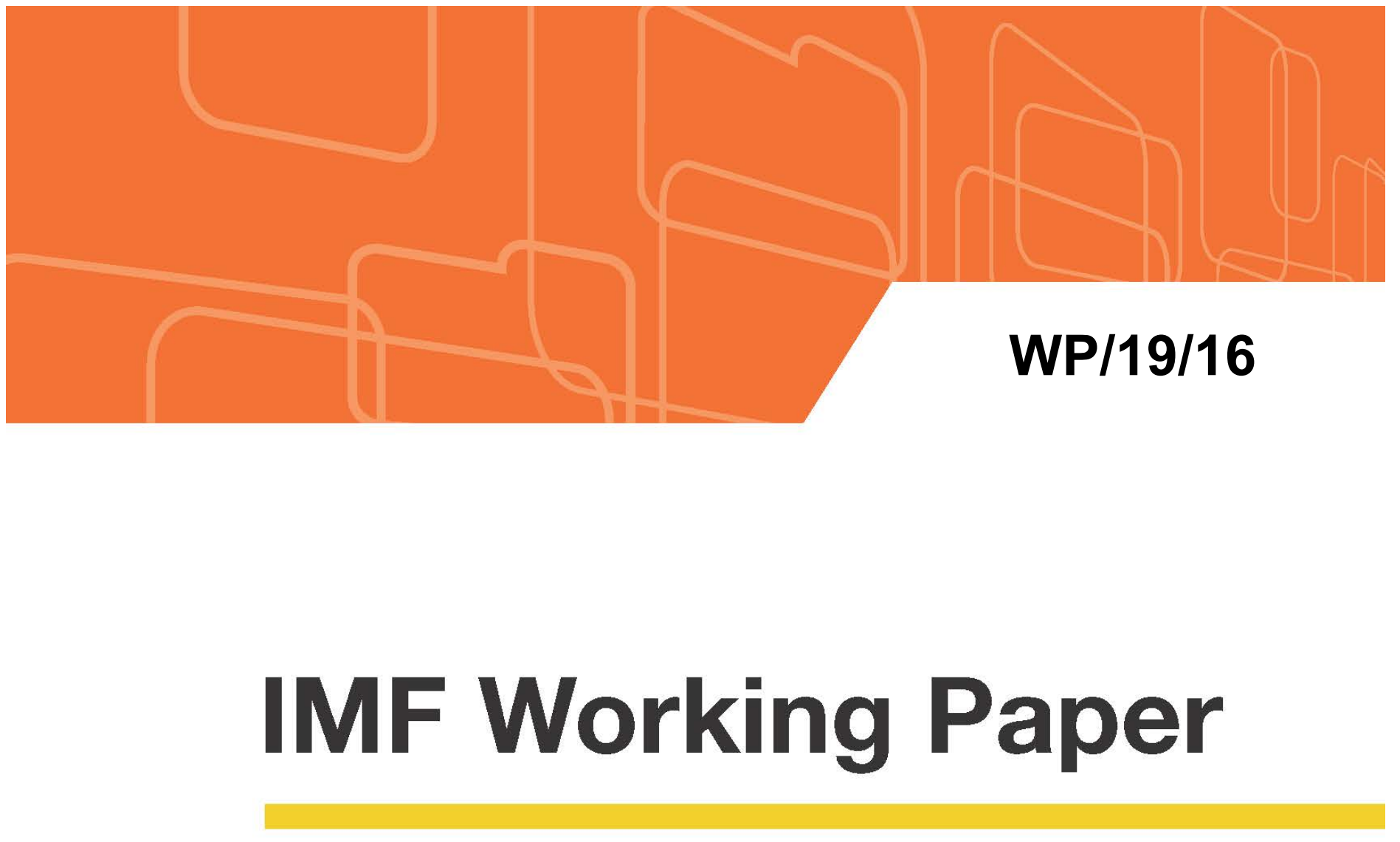

\section{China's Digital Economy: Opportunities and Risks}

by Longmei Zhang and Sally Chen

IMF Working Papers describe research in progress by the author(s) and are published to elicit comments and to encourage debate. The views expressed in IMF Working Papers are those of the author(s) and do not necessarily represent the views of the IMF, its Executive Board, or IMF management.

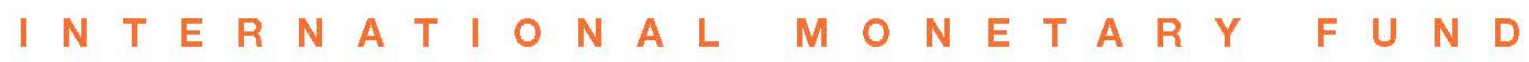




\title{
IMF Working Paper
}

Asia Pacific Department

\section{China's Digital Economy: Opportunities and Risks \\ Prepared by Longmei Zhang and Sally Chen ${ }^{1}$}

Authorized for distribution by James Daniel

January 2019

\section{IMF Working Papers describe research in progress by the author(s) and are published to elicit comments and to encourage debate. The views expressed in IMF Working Papers are those of the author(s) and do not necessarily represent the views of the IMF, its Executive Board, or IMF management.}

\begin{abstract}
China's digital economy has expanded rapidly in recent years. While average digitalization of the economy remains lower than in advanced economies, digitalization is already high in certain regions and sectors, in particular e-commerce and fintech, and costal regions. Such transformation has boosted productivity growth, with varying impact on employment across sectors. Going forward, digitalization will continue to reshape the Chinese economy by improving efficiency, softening though not reversing, the downward trend of potential growth as the economy matures. The government should play a vital role in maximizing the benefits of digitalization while minimizing related risks, such as potential labor disruption, privacy infringement, emerging oligopolies, and financial risks.
\end{abstract}

JEL Classification Numbers: E24, G18, O11, O40

Keywords: Digital economy; Fintech; Productivity; Employment; Financial stability

Author's E-Mail Address: 1zhang2@,imf.org; schen@imf.org

\footnotetext{
${ }^{1}$ We thank Linde Jing for research assistance, and China Academy of Information and Communication Technology and Tencent for data provision. We are also grateful to comments by Chang Yong Rhee, Markus Rodlauer, James Daniel, Sonali Chandra, and Tao Sun.
} 


\section{INTRODUCTION}

\section{Defining ANd Measuring the Digital Economy}

The definition of the digital economy has evolved with the underlying technology. Over the past several decades, the information and communication technology (ICT) sector has undergone rapid development, from microelectronics in the 1940s, to the birth of the computer in the 60s, the introduction of the internet in the 90s, and most recently, blockchain, Artificial Intelligence (Al) and robotics. Correspondingly, new sectors based on the evolving technologies have emerged, such as e-commerce, fintech and driverless cars.

The digital economy can be defined in a narrow or broad sense. In recent years, the explosion of new technologies and its rapid application have spurred another wave of discussion on the digital economy. The narrow definition refers to the ICT sector only, including telecommunications, internet, IT services, hardware and software etc. The broad definition includes both the ICT sector and parts of traditional sectors that have been integrated with digital technology. The G20 uses this broad concept and has defined the digital economy as "a broad range of economic activities that includes using digitized information and knowledge as the key factor of production, and modern information networks as the important activity space" 2 .

Reflecting different definitions, there is a range of measures of the digital economy. The OECD digital economy index uses the narrow definition, which measures the digital economy at 6 percent of GDP in China. By contrast, the China Academy of Information and Communication Technology (CAICT) applies the broad definition to national accounts and measures the size of the digital economy to be about 30 percent of GDP, doubling since 2008. Tencent and Caixin ${ }^{3}$ also have developed measures of digitalization of traditional sectors, though not based on the national accounts framework. In addition, there are also many blended indices, which include the enabling conditions for driving digitalization (such as ICT infrastructure and mobile penetration) and indicators for certain digital industries (such as e-commerce transactions). These indicators include the digital adoption index from the World Bank, digital evolution index from the Fletcher school, network readiness index from World Economy Forum, and the digital economy index from National Bureau of Statistics (NBS).

\footnotetext{
${ }^{2}$ G20 Digital Economy Development and Cooperation Initiative.

${ }^{3}$ Tencent is a Chinese digital company and Caixin is a leading Chinese media outlet.
} 


\section{China’s Digital Economy In The Global ConTeXT}

China's overall digitalization is in the middle of the range globally. The narrow definition (based on the OECD framework) puts the size of China's digital economy at 6 percent of GDP4, compared to 8-10 percent in South Korea and Japan, where the IT sector is more developed and dominant in the economy. The broad definition based on the $\mathrm{CAICT}^{5}$ suggests that the digital economy currently stands at about 30 percent of GDP, compared to 59 percent in the U.S. and 46 percent in Japan, and around 20 percent in Brazil, India, and South Africa. While blended indices do not provide the best measure of the digital economy, they are useful for global comparison given the wide coverage, and show a similar picture: China ranks $50^{\text {th }}$ out of 131 countries based on the World Bank digital adoption index, $59^{\text {th }}$ out of 139 countries in the World Economic Forum index, and $36^{\text {th }}$ out of 62 in the Fletcher School digital evolution index. Notably, these indices are averages of the entire economy, hence mask the diversity across sectors and regions in China, some of which are much more digitalized, such as e-commerce and fintech, and costal regions.
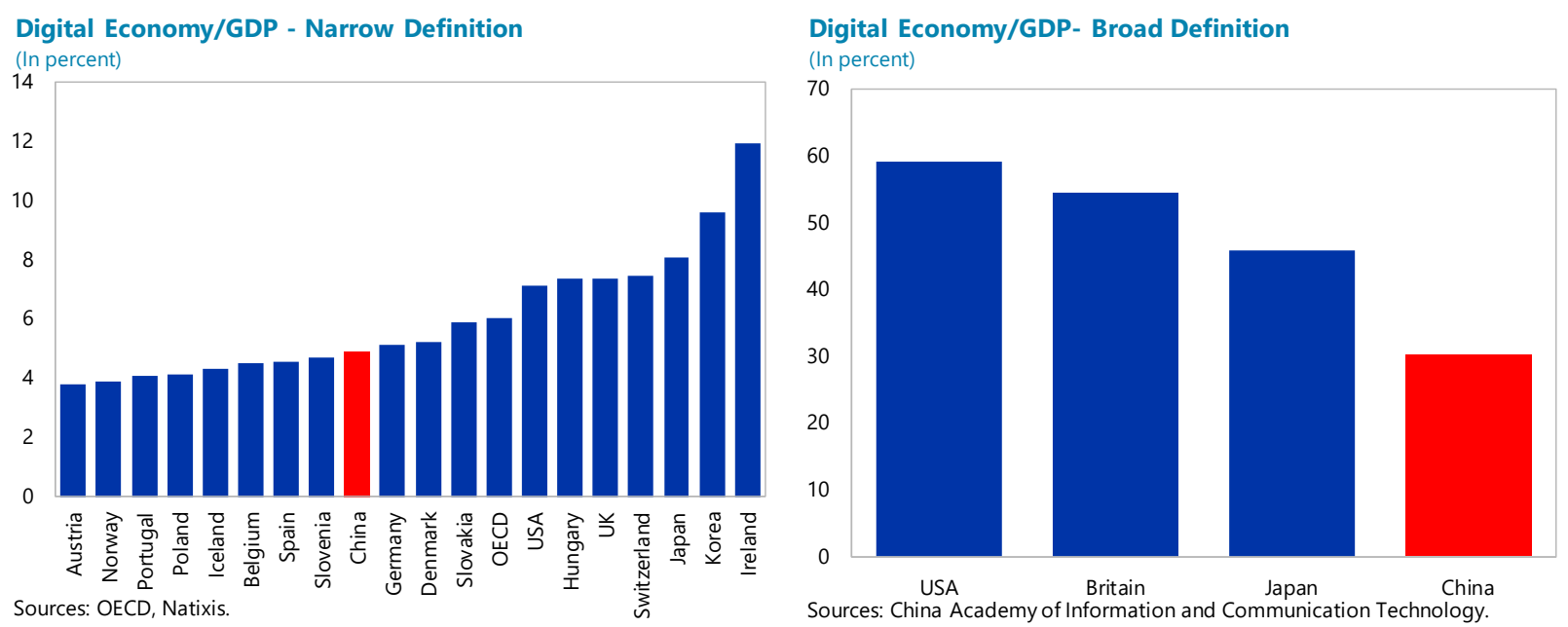

But China has become a global leader in some key digital industries. While overall digitalization is still lagging advanced economies, China has emerged as a global leader in some key new industries.

- On e-commerce: China accounts for over 40 percent of global transactions, and the penetration of e-commerce (in percent of total retail sales) stands now at 15 percent, compared to 10 percent in the U.S. (text chart).

\footnotetext{
${ }^{4}$ Note the numbers presented here are averaged across all Chinese provinces, including e.g. rural China, while in more advanced parts of the economy, the indices suggest much higher level of digitalization.

${ }^{5}$ This methodology calculates the digital capital stock and non-digital stock separately in the economy, and adds the contribution of digital capital stock to the size of digital economy.
} 
- On fintech: Chinese companies account for more than 70 percent of the total global valuations. The value of China's consumption-related mobile payments by individuals totaled US $\$ 790$ billion in 2016, 11 times that of the U.S. Related to the growth of this sizable market, the processing capacity of one of China's largest mobile payments providers is roughly 3 times faster than of U.S. counterparts (text chart).

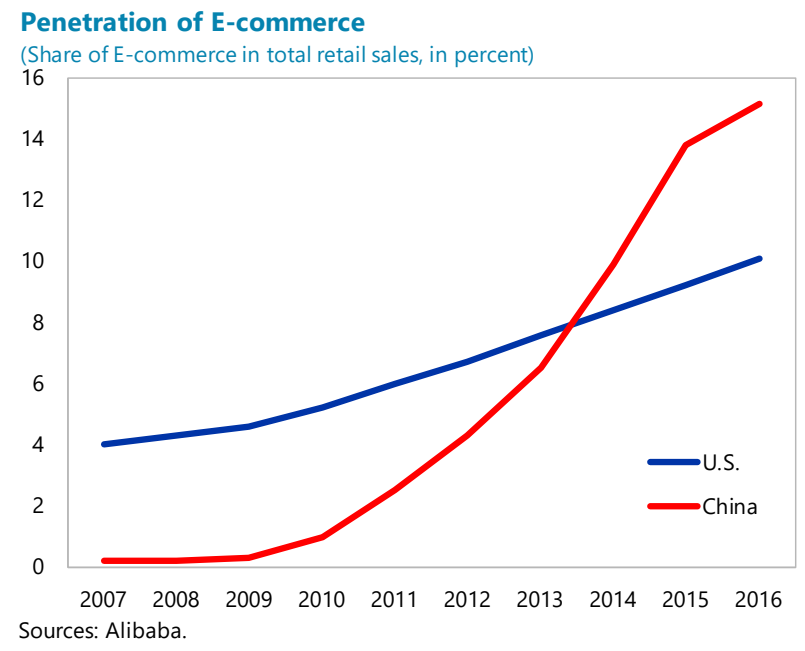

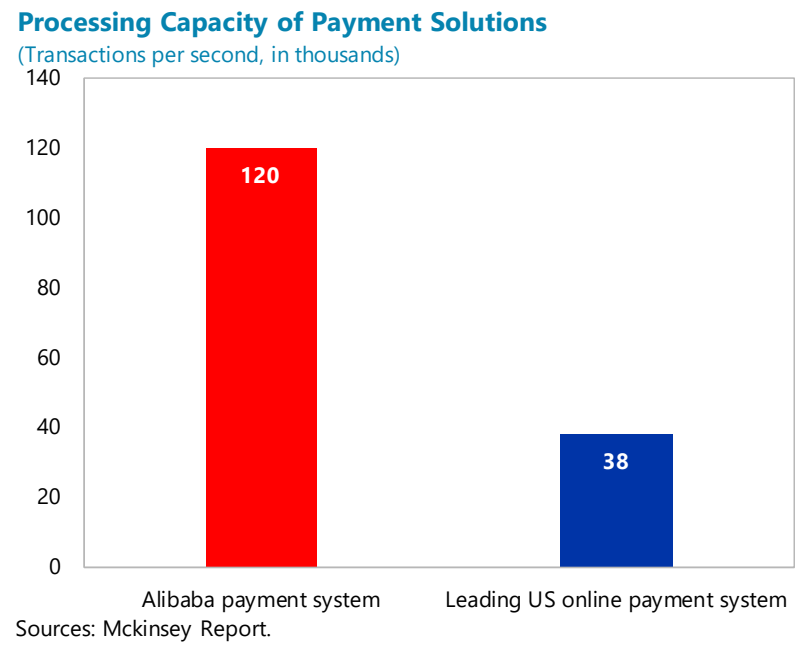

\section{While still at an early stage, China's leading industries have started to have global reach spanning a range of sectors, particularly in fintech.}

- Payments. China's tech giants have been rapidly expanding in overseas markets. Most notably, in the payment industry, Alipay and WeChat Pay, the two popular third-party payment applications in China, are available at physical retailers in 28 countries and regions outside of China for Chinese tourists.

- In e-commerce, Alibaba has set up a global platform connecting sellers and buyers from more than 200 countries, with its total revenue growing by more than 200 percent. Chinese companies have also promoted the development of e-commerce and third-party payments in other countries by investing in local companies, such as Pay TM in India, Airwallex in Australia, and Lazada in South East Asia.

- On cloud computing, Alibaba cloud computing has set up 14 data centers globally, with overseas cloud computing revenues growing at 400 percent.

- ICT exports. Overall, China accounts for 32 percent of global ICT goods exports ${ }^{6}$, and 6 percent in ICT services exports. In 2017, 11 percent of China's ODI was in the ICT sector.

\footnotetext{
${ }^{6}$ Though in value-added terms, the share is much smaller at 11 percent. ICT exports account for 16 percent of China's goods exports, and 40 percent of service exports.
} 
Dajiang, a leading Chinese drone company, now accounts for 50 percent of the drone market share in North America.

China is also a leading global investor in key digital technologies. The venture capital (VC) industry in China has grown rapidly, and increasingly focused on the digital sector. Based on McKinsey estimates, total venture capital in China has surged from US\$12 bn in 2011-2013 (6 percent of global total) to $\$ 77$ billion in 2014-2016 (19 percent of global total), with $\$ 38$ billion invested overseas. The main sectors that attract VC investment include big data, artificial intelligence, and Fintech. Currently, China is in the global top three of VC investors in key digital technologies, including virtual reality, autonomous driving, 3D printings, robotics, drones, and Al.

\section{China's success in the new digital industries reflects a confluence of factors.}

- A relatively large financially-underserved population: In the early days of digital development, financial inclusion was still limited in China compared to advanced economies. In 2011, account ownership among adults was 64 percent in China, compared to more than 90 percent in Japan, Korea and Germany ${ }^{7}$. Small and medium enterprises also have limited access to credit via the formal banking channel. This resulted in sizable demand for services from non-bank financial service providers.

- Government policies have provided a supportive environment for the digital economy in a number of ways. Investment in digital infrastructure has played a particularly important role in facilitating the boom of digital industries. Reflecting continued government investment, the digital infrastructure has improved significantly over the past years, and now broadly in line with advanced economies ${ }^{8}$. Also, the government has adopted light regulation at the early stage of development to allow for innovation. These efforts facilitated the boom of new industries. Relatively limited concerns related to data privacy by the public has also facilitated China's rapid digital development.

\footnotetext{
${ }^{7}$ World Development Indicator.

${ }^{8}$ For example, the connecting speed of fixed broadband is $39 \mathrm{mbps}$, downloading speed $12 \mathrm{mbps}$, higher than in advanced economies like France. The penetration of broadband in households has exceeded 50 percent-- still lower than OECD, though the share of fiber users has reached 77 percent, the number one in the world. By 2016. There were 770 million $4 \mathrm{G}$ users in China, accounting for 58 percent of total mobile users, a higher penetration rate than in OECD (CAICT).
} 
- Scale advantage and enthusiastic adopters/consumers have been a key driver. China has a large base of 700 million internet users and 282 million digital natives (internet users that are less than 25 years old), eager to adopt new technology. By contrast, internet users in India, a country with roughly the same population as China, is about 60 percent of China's size in 2016, while the U.S., the current digital leader, has less than 300 million users reflecting a smaller population size.
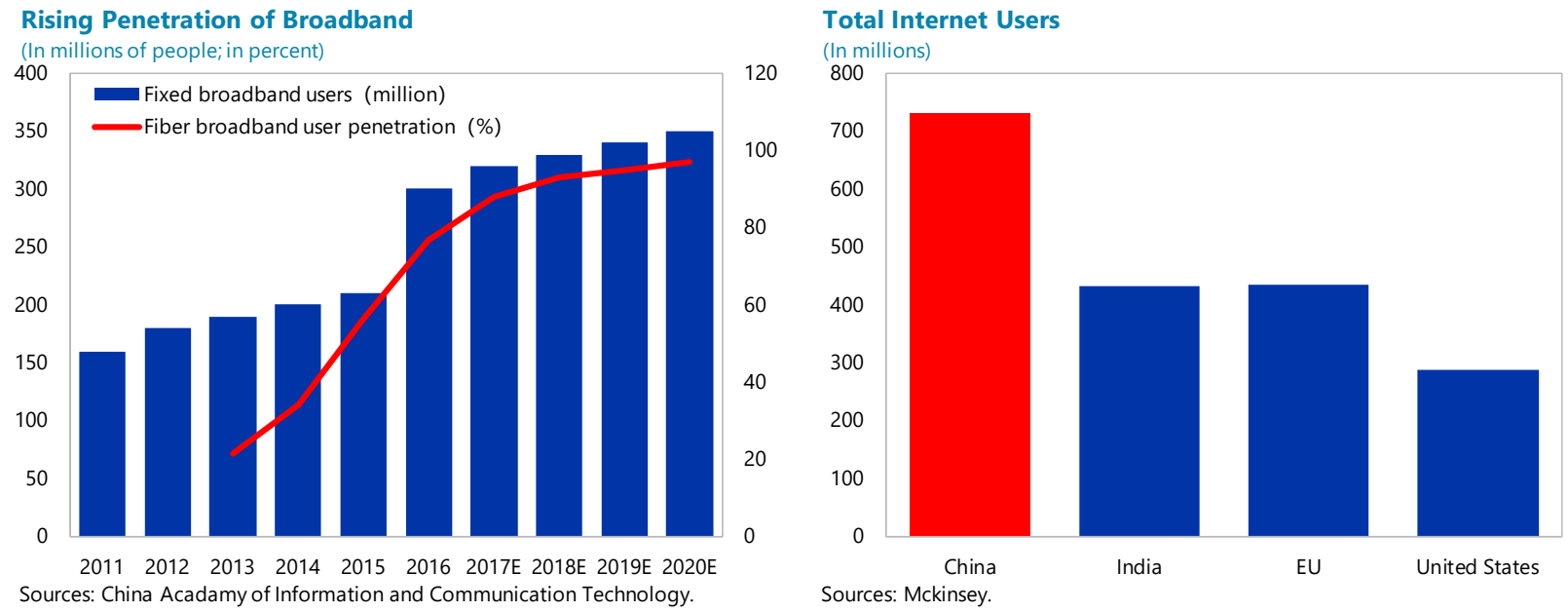

- The ecosystem, developed by the so-called "BAT" (Baidu, Alibaba and Tencent) tech giants, capitalizes on its multi-industry reach and rapid accumulation of consumer data to provide easy access to new products and services to millions of users.

\section{Evolution of The Digital ECONOMY IN CHINA}

China has experienced rapid digitalization in recent years. The size of the digital economy has surged from 15 percent of GDP in 2008 to 33 percent in 2017, mainly driven by the integration of ICT with traditional sectors (text chart). Despite the emergence of various new ICT sectors, their overall size remains small and largely stable at around 7 percent of GDP. On the other hand, the size of digitalized traditional sectors (e.g., financial and entertainment sectors increasingly use ICT in service provision, while industrial production increasingly uses robotics) has expanded from 10 percent of GDP in 2008 to 25 percent in 2017. Based on the Fletcher digital adoption index, China's speed of digitalization is the fastest in their 62-country sample.

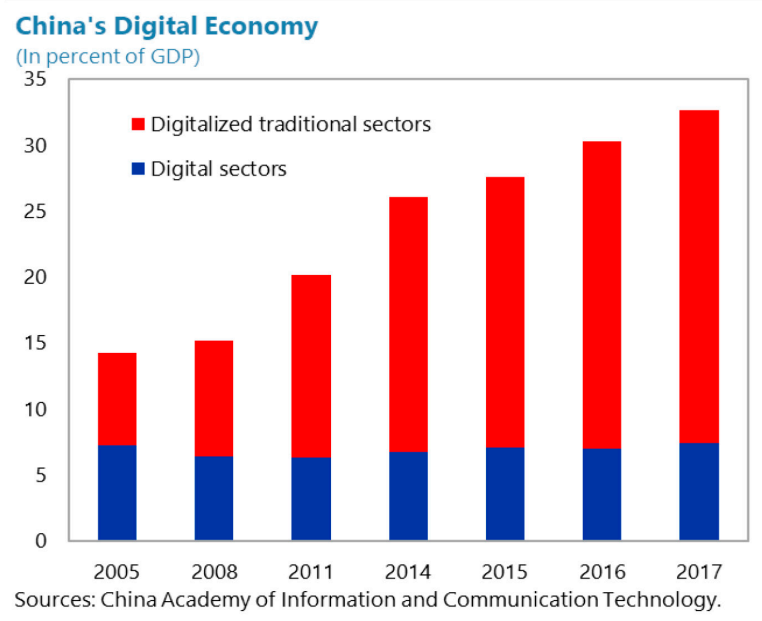


The degree of digitalization varies across provinces. Reflecting the diverse stages of economic development, digitalization across provinces is different, broadly in line with income level (text chart). For example, the digital economy in Beijing and Shanghai is close to 45 percent of its GDP, similar to Japan's level; while in central Henan province, the size is only 15 percent of provincial GDP.

The degree of digitalization varies across sectors.

Overall, the service sector is the most digitalized, with ICT contributing to 33 percent of the sector's valueadded in 2017. The industrial sector is lagging, with ICT contributing 17 percent of its value-added. The agriculture sector is the least digitalized, with only 7 percent of digitalization. There is also substantial variation among subsectors. In services, the most ICTintensive subsectors are mostly in financial services and entertainment; In the industrial sector, the advanced manufacturing sector is also more digitalized.
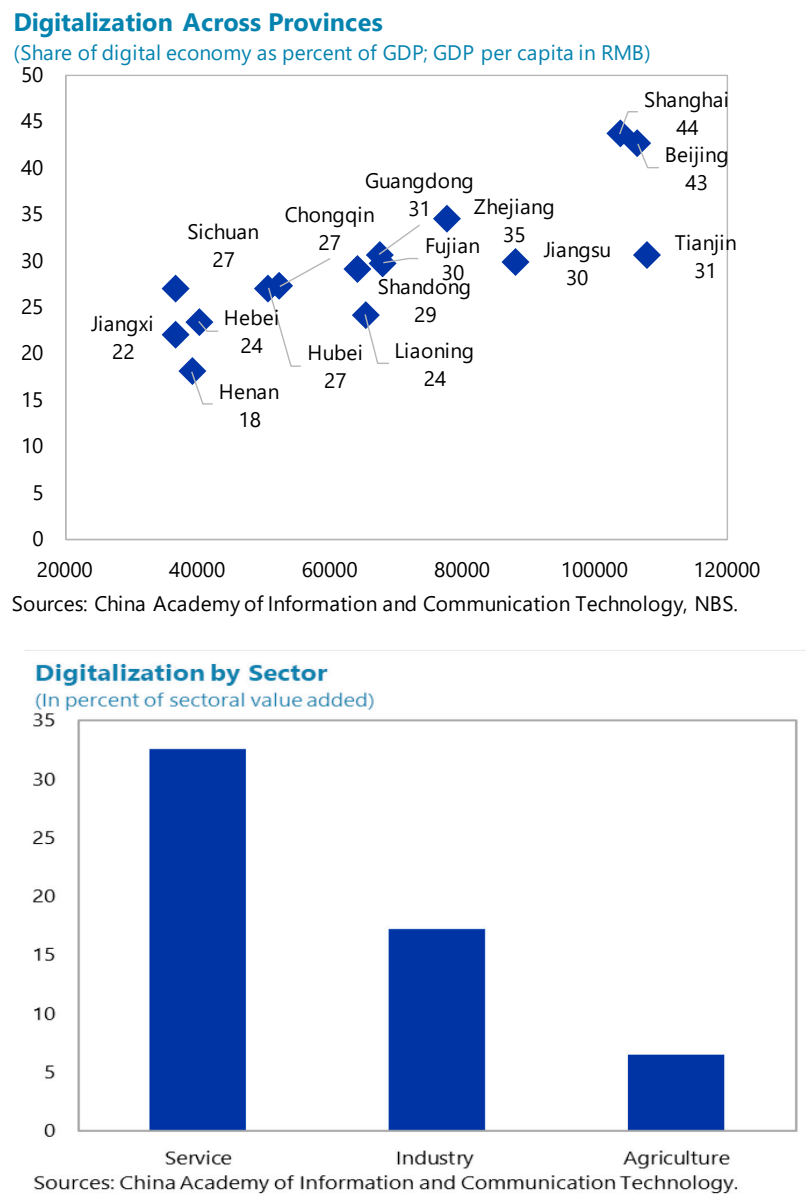

\section{The ReAL IMPACT OF Digitalization}

\section{Productivity}

Theoretically, digitalization can boost productivity, viewed in a growth accounting framework. A salient feature of the digital age is that data has become a new factor of production. This is in contrast to the industrial era, when only capital and labor were used as inputs. The amount of data available has been roughly doubling every two years, and data processing capacity doubles every eighteen months. In addition, a rising share of capital (K) and labor (L) will be using digital technologies to produce output. An existing framework to measure the data stock in a production function is not available. However, by rearranging the production function, the contribution of digitalization could be captured in the Solow residual, hence higher TFP (A) growth. If we proxy the data stock with the size of digital economy, the contribution of digitalization alone could be filtered out.

$$
Y=F(A, K, L) \longrightarrow Y=F(A, D, K, L) \Longleftrightarrow Y=F(A(D), K, L)
$$




\section{Empirical results show a significant impact of} digitalization on productivity growth. Over the past decade, the growth of the digital economy (based on the broad definition by CAICT) has been highly correlated with TFP growth, with a coefficient of 0.5 . Regression results show that a 1 percentage point increase in the overall digitalization of the economy is associated with an increase of 0.3 percentage point of GDP growth (model 1 in appendix), though with a two-year lag $^{9}$. This likely reflects that newly purchased IT equipment would boost

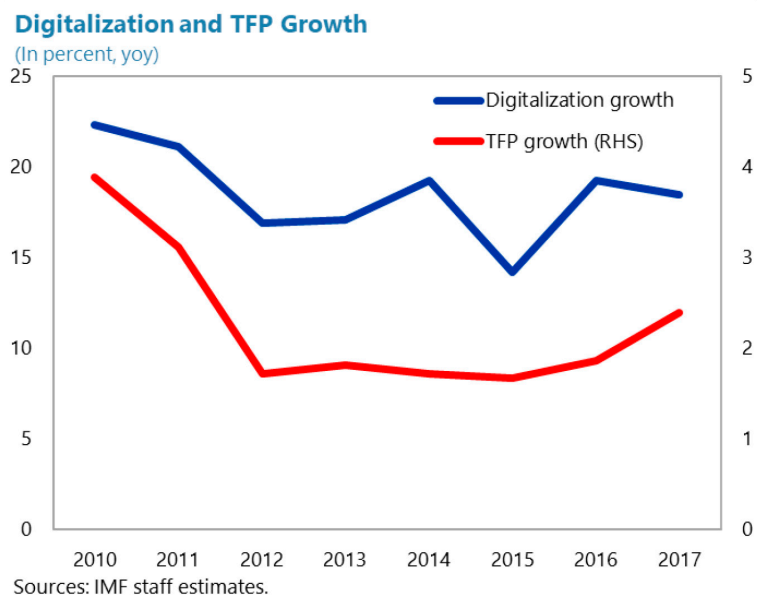
the digital economy simultaneously, but only with a lagged impact on productivity when it is fully integrated into business operations. Province-level regressions, based on Tencent data, also show a similar impact of digitalization on growth, with the impact somewhat higher in developed regions, likely reflecting the higher base of digital economy in these regions, hence a similar percentage increase translates into larger gains. (See appendix for technical details).

\section{There are a few channels through which digitalization has improved efficiency}

- Lower transaction costs. This channel is particularly visible in the fintech industry. Financial transactions that had required visiting bank branches can now be completed in seconds on mobile phones.

- Reduced information asymmetry and better matched demand and supply. The eco-system established by the tech giants in China provide small suppliers with instant access to a large pool of consumers. Big data analytics also reveal consumer preferences and help target service provision.

- Enhanced production efficiency. In the manufacturing sector, automation has led to shorter cycle times, improved quality and reliability.

\section{Employment}

\footnotetext{
${ }^{9}$ Reflecting the uncertainty of digital economy measurement, the estimated growth impact is subject to uncertainty. The net impact could also be smaller as resources are directed away from some traditional sectors amid digital disruption.
} 
Digitalization has created millions of jobs in the new sectors. The booming e-commerce sector and the sharing economy have become a new engine for job creation in China. In the ecommerce sector, Alibaba's platform has almost 11 million SMEs, which have created over 30 million jobs over the past decade. The Didi taxi platform (China's Uber) is connected to 13 million drivers. Employment in the ICT sector has also expanded, though at a smaller scale, with 1.4 million jobs added for high-skill workers in the past five years, and the average wage has doubled since 2012.

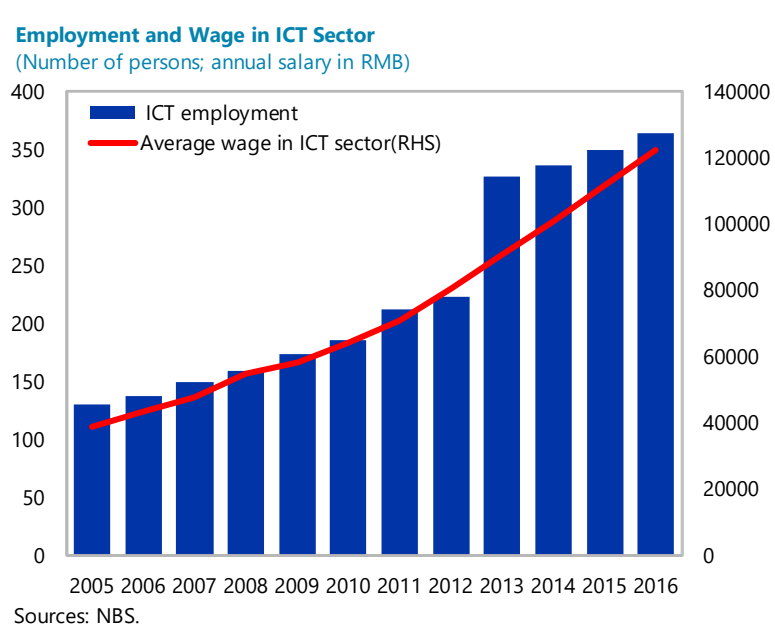

At the same time, millions of jobs have disappeared amid digital disruption. The disruptive impact of digitalization on employment is mostly evident in the industrial sector, while the impact on the service sector has been limited. Industrial employment has fallen by 9 million since 2012, a result of overcapacity cuts, and, to a large extent, automation-driven industrial upgrading. For example, Foxcom, a leading ICT company, has replaced 60 thousand workers with 40 thousand robots. In the service sector, the most vulnerable sector appears to be retail, given the speed of digitalization there. However, despite the surging penetration in E-commerce, the growth of retail employees has been broadly stable.

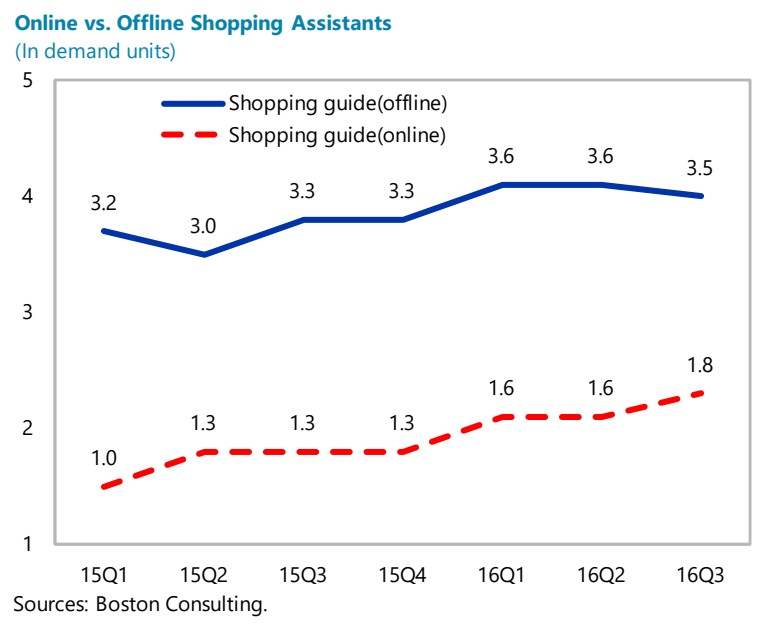

\section{Putting these two divergent trends together, we find that the net impact on employment} has been positive. Despite slowing GDP growth in the past several years, overall employment in China has remained robust as the economy has shifted towards more labor-intensive service sector. Regression analysis suggests that given GDP growth, a one percentage point increase in the digital economy has boosted employment growth by 0.01 percent, with a one-year lag (see appendix for details). Considering the average growth of the digital economy was 10 percent, it has contributed $0.1 \mathrm{ppt}$ to employment growth. Given the aggregate employment growth was 0.2-0.3 ppt in the past few years, digitalization has accounted for one third to half of total employment growth.

\section{Market Structure}

Digitalization has a profound impact on market structure. There are three channels through which digitalization has shaped market structure: 
1) Disintermediation: Digitalization has reduced layers of distribution, linking supply and demand directly through digital platforms.

2) An increase of small players in traditional sectors: digitalization has significantly lowered entry barriers in many sectors, especially consumer goods and services. Small businesses are easily connected to a large consumer base at low cost. This has led to a shift of the market from dominance of big companies to the rising influence of small firms.

3) Oligopoly in platform industries: while barriers are lower in traditional sectors, they are higher in the new industries, especially digital platforms, with only a few firms dominating the space. For example, Alibaba and Tencent dominate the mobile payment sector and have branched out to other parts of the financial services supply chain. Such structure has the advantage of economies of scale or "information scale", but may also lead to price distortions if there is a lack of competition.

\section{Economic Rebalancing}

Digitalization can also promote economic rebalancing. The rapid penetration of digital apps has promoted the development of the service industry, as the "super apps" developed by the tech giants provide consumers a one-stop shop for all services, ranging from entertainment, dining, to education and health. Digitalization can also promote green development, making it easier to track carbon emissions. For example, Ant Financial has developed Ant Forest, a mobile application that integrates carbon emission tracking with user's daily consumption activities. By end 2017, the app has 288 million users, with the cumulative avoided carbon emission reaching 2.05 million tons and the cumulative trees planted amounting to 13.14 million.

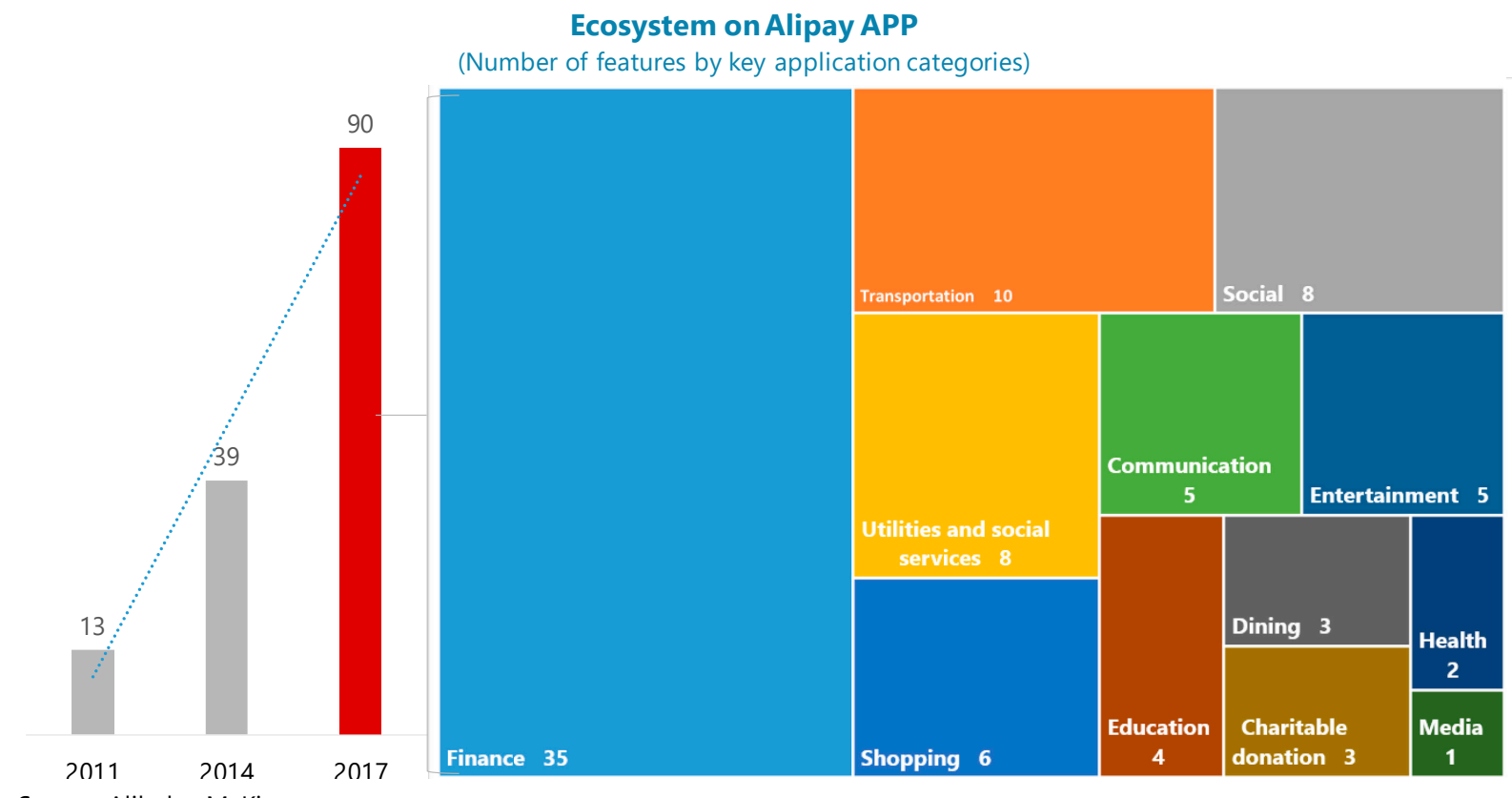




\section{Inequality}

The net impact of digitalization on income inequality is uncertain. On the one hand, digitalization can help targeted poverty reduction, in particular by linking suppliers in remote regions to consumer markets in the metropolis. For example, Alibaba's e-commerce platform has promoted the development of more than 1300 "Taobao villages" in China. Digitalization also contributed to increasing financial inclusion in China, by providing easy mobile access of various financial services to rural residents (World Bank 2017). On the other hand, the disruptive impact of digitalization would mostly be borne by relatively low-skilled workers, while high-skilled workers will likely benefit more with rising employment and faster wage increases, thus potentially widening inequality. In China, inequality has been on a modest downward trend (which has stalled in recent years) post GFC despite the rapid digitalization, reflecting both structural forces and proactive government policies to reduce inequality.

\section{FINTECH AND IMPLICATION ON FINANCIAL STABILITY}

\section{Fintech Developments}

Fintech - the application of information technology to the provision of financial services has surged in recent years, with China emerging as a global leader. The massive scale of China's markets and a "light touch" from regulators and supervisors in the early years supported China's fintech development. Leveraging existing social-media platforms, China's fintech services include several key areas: third-party payments by non-bank digital providers, peer-to-peer lending, internet credit, including microlending, internet-based banking and insurance, digital wealth management, and credit-ratings. Notably, large, dominant fintech players in China have branched beyond their traditional niche to other areas of the finance supply chain, building an integrated ecosystem of financial services that link customers with businesses.

\section{Third-party mobile payment on non-bank platforms is one fintech area where China has} made notable advances. The rapid adoption of third-party payments was enabled by technology, the proliferation of e-commerce and social media, as well as China's late-mover advantage in the digitization of money. A well-known, early entrant to this arena is Alipay, which in 2004 launched e-payment options on the e-commerce platform owned by its parent company Alibaba. Since then, applications geared towards mobile payments have multiplied while their usage has increased dramatically. By one estimate, payments made through third-party processors reached over RMB 119 trillion (or roughly US\$18 trillion) in 2016 (PBOC/World Bank). Alipay and WeChat Pay-launched by Tencent-now dominate this space with 84 percent of China's market share. Most of mobile payments are small, at no more than $\$ 20$ per transaction. However, their use has dominated total transactions, with mobile payments making up about 75 percent of total payment in 2016. In the U.S., 20 percent of e-commerce payments come from mobile phones (Goldman Sachs 2017). 
Peer-to-peer lending ("P2P") - loan transactions on an internet platform - had also increased rapidly until recently. Rather than credit intermediaries, P2P platforms are information intermediaries as they gather information, evaluate credit, facilitate information exchange and match borrowers and lenders. These platforms get their funding primarily from retail investors. Limited investment channels and interest rate caps in the past, combined with banks' preference to lend to SOEs and large corporates provided fertile ground for the growth of P2P platforms. By the end of 2016, total P2P transaction volume reached RMB 2.06 trillion, more than double in just a year and the equivalent of 12 percent of total bank loans extended in 2016 (PBOC). The maturity of these loans is short, averaging 5 to 8 months; the

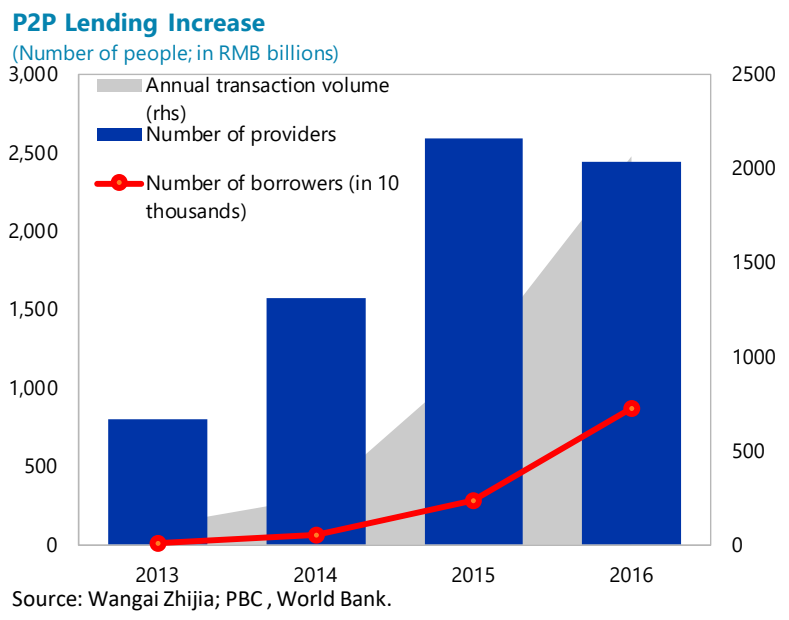
average rate of return was 10.5 percent in 2016, falling from over 13 percent a year ago (PBOC). Though recently, with regulatory tightening, the number of P2P platforms has fallen significantly.

Micro lending from internet banks has also flourished. There are three categories of micro lending: financing for online store operators such as loans from Ant Financial to Taobao store owners, consumer lending for online shoppers such as Ant Credit Pay, and small loans to households, particularly agricultural households facing financing constraints. Three banks (WeBank, MyBank and XW Bank) all operate with commercial banking licenses and dominate this space. For example, WeBank offers unsecured microloans (Weilidai) and auto microloans (Weichedai) that can lend up to RMB 200,000 without collateral or guarantee. Compared to traditional banks, internet banks focus mainly on small loans and leverage big data gathered from e-commerce platforms for operations and credit risk assessment. Similarly, internet-based insurance schemes are mainly of low value, and short term, and offer standardized, simple contract terms.

The emergence of Yuerbao-an online money market fund developed by Ant Financial in 2013 vastly expanded investor participation in fund management and is now the largest money market fund in the world. It mobilized unused funds in Alipay accounts and lowered the investment threshold from a typical RMB 1,000 to just RMB 1. Pooled funds from Alipay customers are invested in money market funds and bank deposits. Accessibility is easy customers can withdraw money almost immediately, track accrued interests daily and use money in the account for payments via Alipay. Alipay's ease of use helped the platform to rapidly expand its user base and funds under management. By the end of 2017, the number of users swelled to 474 million (about 30 percent of the population) and funds under management rose to RMB 1.6 trillion, 2.5 percent of total bank deposits.

China's fintech development has a uniquely high level of integration across different parts of the finance supply chain. Companies that had early successes in the fintech space have built 
an ecosystem along the entire finance supply chain, broadening and linking their core businesses to consumers. Examples include tech giants Alibaba, Ant Financial, Tencent, JD.com, Baidu, and the financial conglomerate Ping An. For example, beyond Alipay, Ant Financial also provides consumer loans SME lending through Ant Credit Pay, micro loans to SMEs, asset management services through Ant Fortune, and private and independent credit scoring service. By contrast, firms in the U.S. such as Visa and MasterCard, or digital payment companies such as PayPal, have focused almost exclusively on one or a few core businesses with no offline integration across business lines.

\section{Meanwhile, the increasing use of third-party payment services has affected bank} operations. Banks are increasingly reliant on these third-party service providers for operational support of technology-based financial services. As a result, the delivery of these services has become more modular, often independent of bank operations themselves. For example, traditional deposit taking banks could be linked to a third-party payment platform that allows its depositors to pay for purchases; in the process, it relies on the payments provider to monitor the flow of money from online transactions. Banks outsource these services, motivated by cost reduction and operational flexibility. However, although operations can be outsourced, the risks and liabilities associated with these operations remain with the banks. The size and impact of those risks could be significant and raise governance and risk management questions, such as the adequacy of internal controls and the availability of proper internal expertise to monitor and manage these risks. More broadly, these challenges raise the question of whether large tech companies that provide these services should be supervised and folded into the purview of financial regulators.

\section{Implications for Financial Stability}

The fintech industry is transforming financial service provision and market structure. Large fintech firms have created universal banking and a fintech ecosystem via accumulating a large pool of customers over commerce, gaming, and social network businesses. The benefits provided by these large fintech companies are many, including lowering online payments costs, increasing service provision to traditionally under-served populations and dramatically increasing the lending transaction volume. Meanwhile, banks are losing their advantages in the traditional consumer market and are increasingly becoming the payment channel or middle or the back office of these online payment service providers.

\section{The unique blend of large hybrid technology/financial companies that dominate service provision could have sizable spillover effects on the financial system.}

- Online payment service providers operate in the shadow banking system; they pool cash from banks, invest in interbank CDs or micro loans, resulting in credit and maturity transformation. Actual fund flows are difficult to monitor as these payments providers operate outside of the purview of regulatory supervision. 
- Most fintech companies that are engaged in consumer lending follow a capital-light model; consumers could suffer significant losses if these companies face a liquidity crunch.

- KYC - "know your customer" - standards are weak - creating potential for embezzlement and fraud. Limited clarity on the size and nature of financial transactions, combined with opaque identities of many of the users have raised AML/CFT concerns.

- Close integration across different segments of financial services could exacerbate risk spillovers across the financial services chain, amplifying losses in the event of a downturn.

The challenges of monitoring transactions in an integrated, closed-loop financial system have increased. These closed-loop platforms differ from their open-loop counterparts such as credit card payments that link all digital payments to a personal account. Instead, these systems operate like gift cards and allow users to manage payments directly on mobile applications, while limiting usage to only specific vendors. A closed-loop ecosystem of large players allows credit to be created outside of the central bank's purview. Significant policy efforts have been made to address such loopholes, e.g. the money market fund Yuebao is now captured in the PBC's money supply statistics; money flow in the third-party payment system will now also be captured by Wanglian, the newly established central clearing system. Still, the current system does not offer a clear framework for jurisdictions over data ownership, or data sharing between different market participants and regulators.

\section{The Chinese authorities initially adopted a "light touch" regulatory approach during the} early years of fintech development. The scope of earlier initiatives and their spillover to the rest of the economy were limited, requiring little regulatory intervention. Moreover, there was a sense that nascent industries needed space to flourish. For example, a cap on the value of online money transfers was not introduced until 2016, 11 years after Alipay first unveiled the platform. While Taobao introduced online payment transactions in 2003, the government did not release licenses to third party payment businesses until 2014.

\section{Amid robust fintech growth in recent years, regulators have embarked on a set of regulatory initiatives to strengthen regulatory oversight. Moreover, fintech developments} raise issues related to public policy considerations beyond financial stability. Issues such as safeguarding data privacy, cyber-security, consumer protection, fostering competition and compliance with AML/CFT are becoming an integral part of fintech development and regulation.

- The Guiding Opinions from the PBC and nine other ministries in 2015 and the Provisional Rules from CBRC and three other ministries in 2016 laid out the regulatory framework for fintech credit. These policies emphasized that fintech credit platforms - and their online lending services - are financial information intermediaries, involving financial intermediation and related risk management (FSB/CGFS, 2017).

- In a series of announcements from June 2015 to October 2016, the authorities laid out a comprehensive overarching framework, defining who and how they will regulate each 
business activity within the "internet finance" industry, putting more checks and balances on fintech companies' business practices. These announcements focus, in particular, on compliance, funding models, as well as consumer protection.

- A new FinTech committee, created in May 2017, will be responsible for coordinating between different financial regulators and industry participants.

- Domestic crypto-asset exchanges - deemed speculative and not providing benefits to the real economy - have been closed. The PBC does not recognize Initial Coin Offering ("ICO") or other types of crypto tokens as a payment instrument. Trading of bitcoins in RMB is banned while trading of bitcoins with foreign currencies discouraged.

- A centralized clearing house for all third-party payments, Wanglian - third party payment system "union" or "association", was established in March 2017 to clear all third-party payments and will end the current arrangements where most third-party players connect to each bank directly. Wanglian will thus prevent companies from circumventing regulator oversights on transaction natures and fund flows. Meanwhile, the PBC has mandated centralized custody of all client funds from online payment service providers, requiring these providers to deposit all client funds at the PBC.

\section{Prospects}

China is expected to continue its rapid digitalization. With its large base of internet users, well-established online ecosystem, improving digital infrastructure, consumer-driven digitalization is expected to continue. In addition, the next wave of digitalization will increasingly come from the business sector, into the broader integration of ICT with the production process. Such integration may also accelerate reflecting targeted government support as outlined in China Manufacturing 2025. Assuming continued highspeed digitalization, the size of the digital economy in China is likely to reach close to 50 percent of GDP by 2025, similar to the level in Japan today.

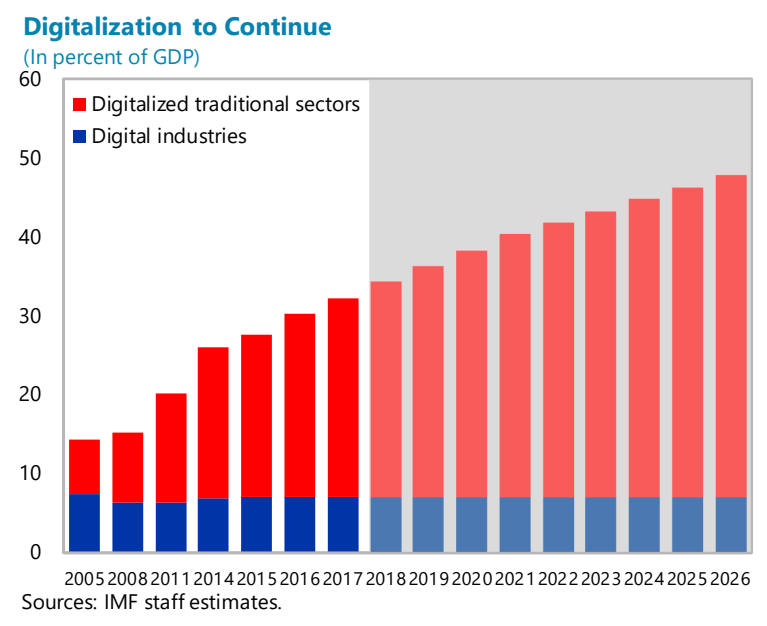


Despite digitalization-led efficiency gains, China's potential growth will slow as the economy matures. With rising income level, China's growth will naturally moderate as it gets closer to the technological frontier. In particular, since 2012, China has started a structural shift from industry to services and is expected to continue this transition in the next few decades (Zhang 2016). As services productivity is much lower than industrial productivity in China, such a shift will inevitably put downward pressure on potential growth. Digitalization can moderate the slowdown by improving sector-specific productivity, in

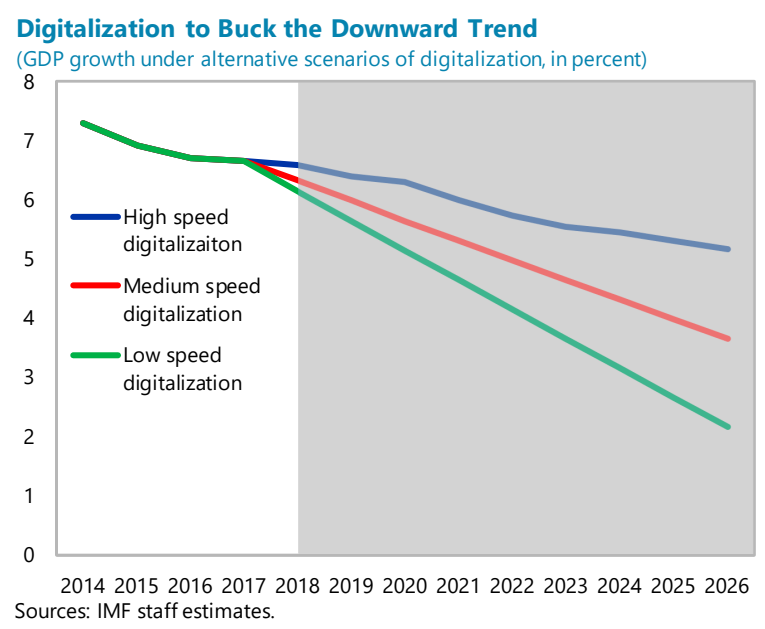
particular if the current high speed of digitalization could be maintained, but is not likely to reverse the downward trend.

Digitalization will likely result in industrial job losses going forward, but the overall impact on employment is likely to be contained. China's current robot intensity in the industrial sector is 5 percent, compared to 18 percent in the U.S. and 60 percent in Korea. Automation will continue replacing low-skilled workers as China goes through industrial upgrading. Yet China is well placed to handle such shocks, as the shift towards the services sector is expected to create millions of new jobs. If industrial workers could be trained and work in services, overall employment would remain robust, despite an expected slowdown in employment growth rate to below 0.1 percent. In addition, the shrinking working age population will limit labor supply, and contribute to a tight labor market.

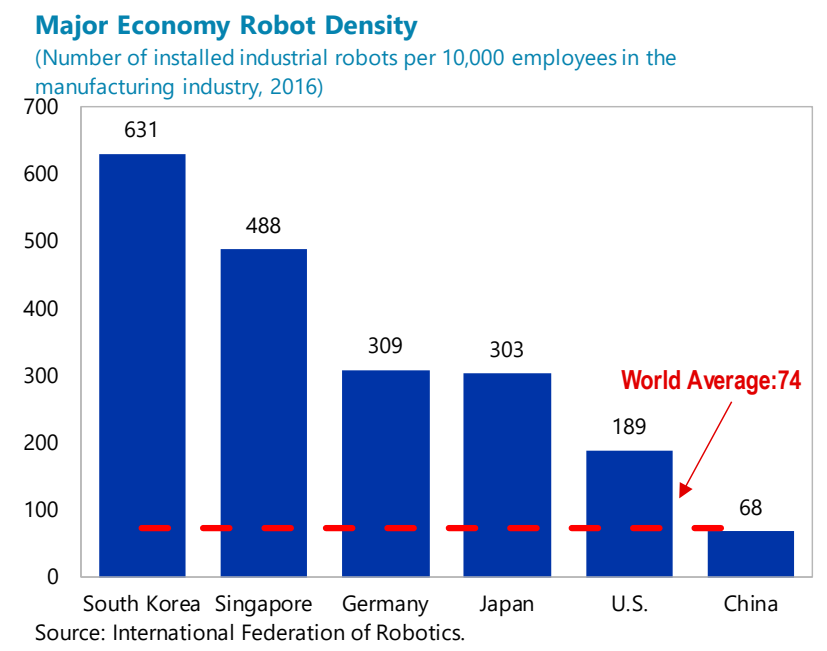

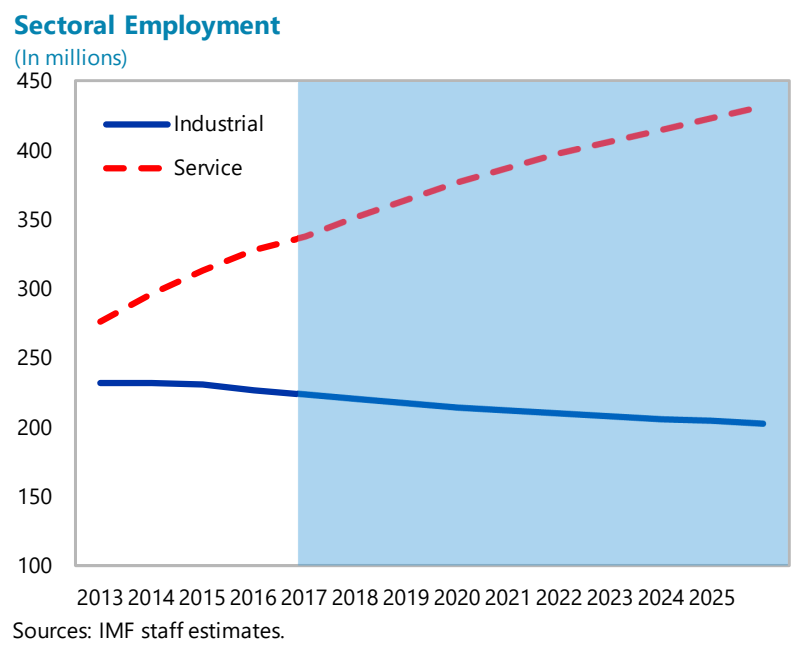

Digitalization may also lead to increasing labor market polarization. Digitalization will have vastly different implications depending on the nature of the tasks. The most vulnerable jobs are typically mid-skilled jobs, as such jobs consist of routine tasks which follow a precise set of procedures easily automated by ICT; tasks performed by high-skilled labor are complementary to 
ICT and those performed by low-skilled labor, such as caregiving services, are largely neutral (Das and Hilgenstock 2018). Therefore, digitalization could lead to increasing labor market polarization, rising wages and employment of high and low-skill labor relative to those in the middle, or the "hollowing out" of middle. This has been widely observed in advanced economies in the past (text chart shows the experience of the U.S.). With China entering more advanced stages of digitalization, such polarization could also increase.

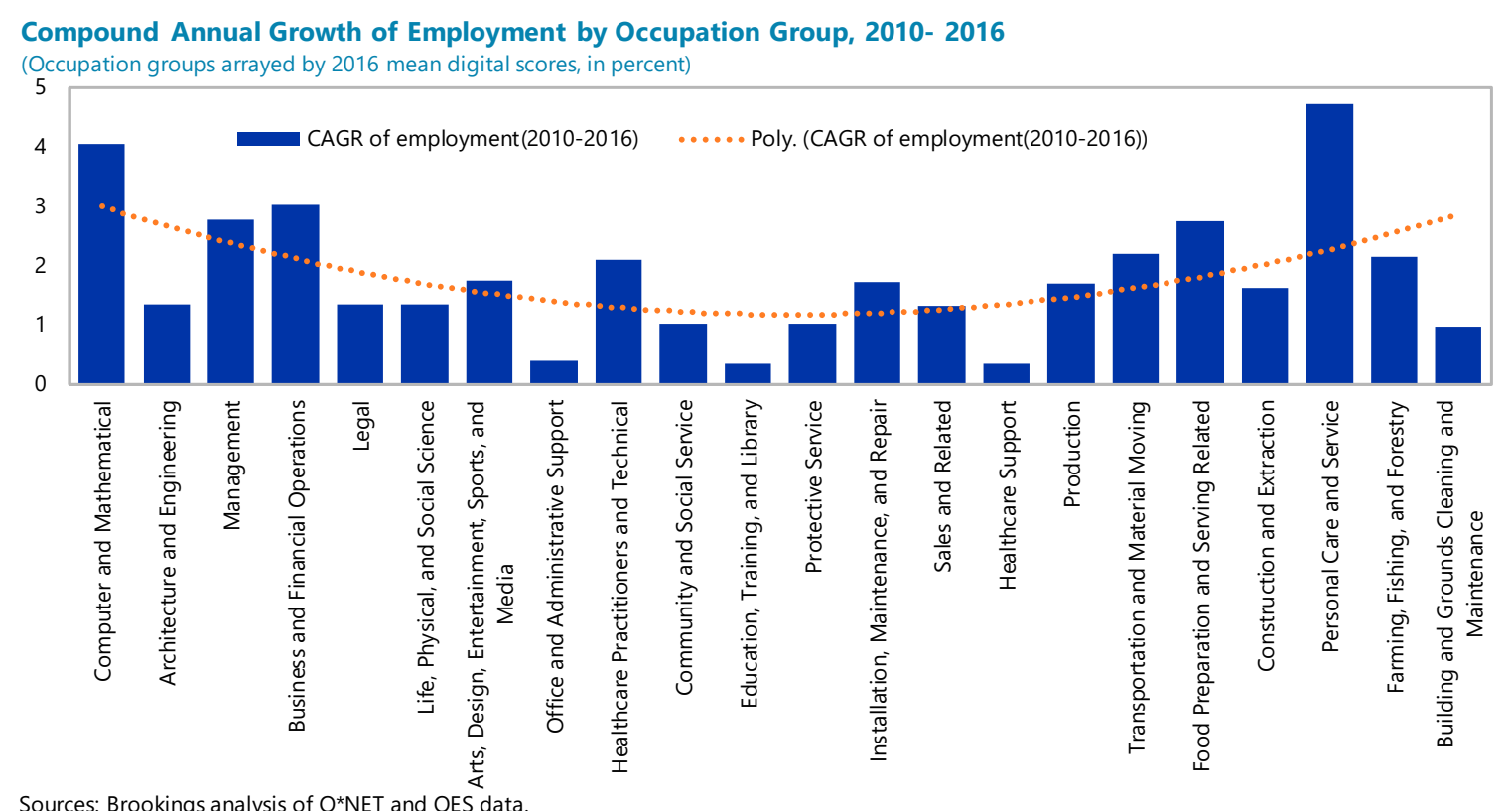

Downside risks to employment emerge if artificial intelligence is applied on a large scale.

Currently $\mathrm{Al}$ is still at an early stage of application, but developing rapidly. Machine Learning, a subset of $\mathrm{Al}$, is already being applied and increasingly so, particularly in the financial sector. World Bank (2016) estimates that 77 percent of employment in China is susceptible to automation. There is considerable uncertainty on the future evolution of Al, including technology bottlenecks, needed legal framework, and social acceptance. But a surge in Al application may lead to larger-than-anticipated disruption in the labor market.

\section{Conclusions And Policy Recommendations}

Digitalization brings significant benefits to the economy, but also risks. Digitalization can boost productivity, promote rebalancing, and create jobs in new sectors. On the other hand, digitalization could disrupt traditional sectors, lead to job losses, especially mid-skill workers in the manufacturing sector. Similarly, while fintech has improved service efficiency and expanded financial inclusion, it also created financial stability concerns and created new challenges for regulation and supervision. Going forward, continued digitalization will provide new sources of growth, yet its impact will likely not be large enough to reverse the gradual downward trend of China's potential growth.

The government can play a pivotal role to maximize the benefit of digitalization while minimizing its risks. Key measures include: 
- Active labor market policy. A key risk of digitalization is its potentially disruptive impact on certain segments of the labor market. To smooth labor transition, the government could usefully play an active role in retraining the labor force.

- Strengthening the social safety net: For affected workers who are close to the retirement age, a strong social safety net will be important to ensure minimum living standards.

- Competition policy: Oligopoly is common in China's newly-emerged digital industries. It is therefore critical to promote competition (including entry of foreign firms) and encourage data sharing among the companies. Policies that support open networks and foster competition could be considered. China is seen as having one of most stringent requirements on local data storage and cross-border data transfers (see, for example, survey from the European Center for International Political Economy); such requirements could present obstacles to further integration into the global innovation system.

- Comprehensive fintech supervisory oversight to close regulatory gaps. Fintech, and more broadly, the burgeoning digital economy are merging multiple business lines. Regulators and the industry need to coordinate to focus on "form over substance" regulation to close loopholes and to allow for more effective and integrated supervision across companies and industries. Regulatory sandboxes are useful to facilitate pilot fintech trials. At the same time, liquidity buffers and capital adequacy considerations would need to reflect risks embedded in fintech activities. Given the transformative nature of fintech, regulators will need to stay nimble to head off emerging risks, for example, by strengthening data gathering and "know your customer" requirements for third-party payments.

- Data privacy and consumer protection. Supervisors should communicate and coordinate with relevant regulators and authorities in charge with data and consumer protection to enhance regulation and supervision of fintech entities (Basel Committee on Banking Supervision, 2018). The government could also establish laws to protect consumers' data privacy and jurisdictions over data sharing.

- E-government. The government could improve the efficiency of public services through digitalization. The United Nation e-government index shows the digitalization of public services in China ranks $63^{\text {rd }}$ out of 193 countries in 2016, hence there is significant room to catch up. 
- Continued support for digital-

infrastructure. With the fast evolution of digital technology, the underlying digital infrastructures require constant upgrading, hence continued government investment. In addition, more efforts are needed to improve internet penetration in rural areas, which remains low at 19 percent of the rural population.

- Education policy. Increasing focus on ICT education is needed in universities and vocational schools.

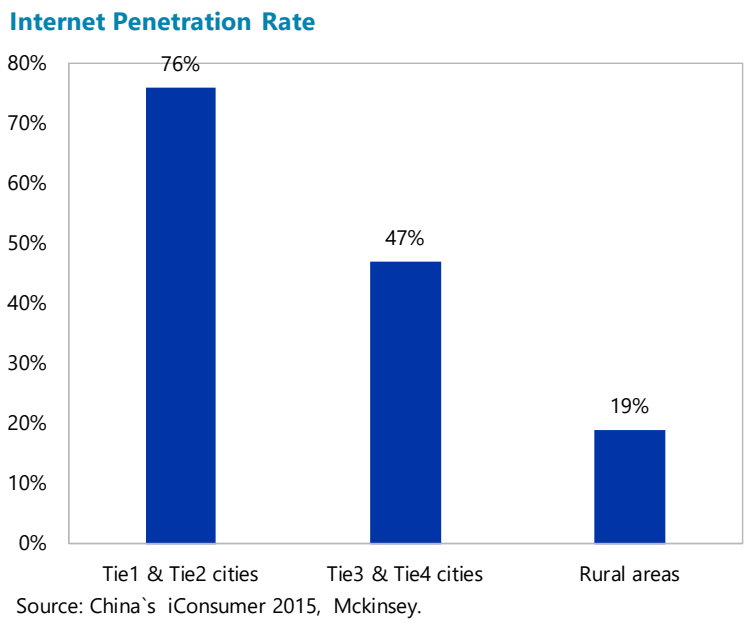

- More active role in setting global standards. As a global leader in e-commerce and fintech, China could play an active role in collaborating with other countries setting global standards on regulating these industries, as well as on issues related to cyber security, global digital standards and governance. 


\section{References:}

AliResearch, 2016, Three Future Trends in the E-commerce Logistics Industry, May 2016.

AliResearch, 2017A, Five Years of Innovation-10 Key Words about China`s Internet Industry, October 2017.

AliResearch, 2017B, Digital Economy 2.0, January 2017.

AliResearch, 2017C, Report on China's Taobao Village, December 2017.

Basel Committee on Banking Supervision, 2018, Sound Practices - Implications of Fintech Development for Bank and Bank Supervisors, February 2018.

Boston Consulting Group, 2017 A, Towards 2035: The Future with 400 billion Digital Employment, , January 2017.

Boston Consulting Group 2017 B, Towards 2035: The Battle on Human Capital for Digital Economy, January 2017.

China Academy of Information and Communications Technology, 2017A, White paper on digital economy development, July 2017.

China Academy of Information and Communications Technology, 2017B, White paper on digital economy development of G20 countries, December 2017.

China Academy of Information and Communications Technology, 2017C, Internet Development Trends Report , December 2017.

China Development Forum, 2017, The Future of Artificial Intelligence in China, March 2017.

China Internet Information Center, 2017, China statistical report on internet development, January 2017

Das, M. and B. Hilgenstock, 2018, "The Exposure to Routinization: Labor Market Implications for Developed and Developing Economies", IMF working paper 18/135.

Didi Taxi 2017, The Big Data Report on Smart Travel, January 2017.

Financial Stability Board and Committee on the Global Financial System (2017): FinTech credit: Market structure, business models and financial stability implications, May 2017

Goldman Sachs, 2017, The Rise of China FinTech, August 2017 
Guizhou Global Big Data Exchange, White paper on China big data exchange, May 2016.

Mckinsey, 2017A, Digital China: powering the economy to global competitiveness, December 2017.

Mckinsey, 2016, Where machines could replace humans and where they can't(yet), July 2016.

Mckinsey, 2017B, Artificial Intelligence: The next digital frontier? June 2017.

Tencent Research Institution, 2017, The 2017 China "Internet Plus" digital economy index, April 2017.

U.S. Department of Commerce, The Emerging Digital Economy, 1998, 1999.

World Bank, 2016, World Development Report 2016: Digital dividends, January 2016.

World Bank and the People's Bank of China, 2018, Toward Universal Financial Inclusion in China, February 2018

World Economic Forum, 2016, The Global Information Technology Report 2016, July 2016.

Zhang, L., 2016, "Rebalancing in China-Progress and Prospects," IMF working paper 16/183. 


\section{Technical Appendix: Impact of Digitalization on Productivity and Employment}

This section quantifies the impact of the digitalization on productivity and employment using regression analysis, including both at the national level and panel regression at the provincial level.

\section{Least square regression at national level:}

Data: annual data on digital economy from China Academy of telecommunication Research, interpolated into quarterly data (DEI). GDP, investment (INV), and employment (EMP) are quarterly data from National bureau of statistics. All variables are expressed in growth terms.

Regression: $\mathrm{GDP}_{t}=\alpha_{0}+\alpha_{1} \times \mathrm{DEI}_{t-l}+\alpha_{2} I N V_{t}+\alpha_{3} E M P_{t}+\varepsilon_{t}$

$$
E M P_{t}=\alpha_{0}+\alpha_{1} \times \mathrm{DEI}_{t-l}+\alpha_{2} G D P_{t}+\varepsilon_{t}
$$

\section{Results:}

Impact on growth

$$
\text { Model } 1 \quad \text { Model } 2 \quad \text { Model } 3
$$

\begin{tabular}{lccc} 
VARIABLES & GDP growth & GDP growth & GDP growth \\
\hline lagged & & & \\
digitalization & $0.34 *$ & $0.47^{* * *}$ & 0.29 \\
& $(0.18)$ & $(0.12)$ & $(0.26)$ \\
investment & $0.68 * * *$ & $0.71 * * *$ & \\
& $(0.11)$ & $(0.12)$ & \\
labor & 7.9 & & $24.6 * * *$ \\
& $(8.1)$ & -3.87 & $(0.03)$ \\
Constant & -1.8 & $(2.01)$ & \\
& $(1.98)$ & & \\
& & 44 & 44 \\
Observations & 44 & 0.55 & 0.31 \\
R-squared & 0.56 & & \\
\hline
\end{tabular}

Robust standard errors in parentheses

$* * * \mathrm{p}<0.01, * * \mathrm{p}<0.05, * \mathrm{p}<0.1$ 
Impact on employment

VARIABLES Employment Growth

lagged

digitalization

$0.013 * * *$

$(0.002)$

GDP growth $\quad 0.005 * * *$

(0.002)

Constant

0.007

(0.04)

Observations

R-squared

0.57

Robust standard errors in parentheses

$* * * \mathrm{p}<0.01, * * \mathrm{p}<0.05, * \mathrm{p}<0.1$

\section{Panel regression at provincial level}

Data: annual data on digital economy index from TenCent, interpolated into quarterly data (DEI). Provincial GDP, investment (INV), are quarterly data from National bureau of statistics. All variables are expressed in log terms, except GDP/Capita in level term.

Regression: $\mathrm{GDP}_{i, t}=\alpha_{0}+\alpha_{1} \times \mathrm{DEI}_{i, t}+\alpha_{3} \times G D P /$ Capita $_{i, t-1}+\alpha_{2} I N V_{t}+\eta_{i}+\chi_{t}+\varepsilon_{i, t}$

Results:

\begin{tabular}{|c|c|c|c|}
\hline & Full Sample & $\begin{array}{l}\text { Developed } \\
\text { Regions }\end{array}$ & $\begin{array}{l}\text { less developed } \\
\text { regions }\end{array}$ \\
\hline VARIABLES & GDP growth & GDP growth & GDP growth \\
\hline \multirow[t]{2}{*}{$\begin{array}{l}\text { lagged } \\
\text { digitalization }\end{array}$} & $0.27 * * *$ & $0.35 * * *$ & $0.27 * *$ \\
\hline & $(0.05)$ & (0.04) & (0.09) \\
\hline \multirow[t]{2}{*}{ investment } & -0.05 & 0.13 & -0.05 \\
\hline & $(0.03)$ & (O.1) & -0.04 \\
\hline GDP/Capita & $\begin{array}{c}-4.6 \\
(1.14)\end{array}$ & $\begin{array}{c}-4.25 * * * \\
(0.9)\end{array}$ & $\begin{array}{c}-6.5 * * * \\
(2.94)\end{array}$ \\
\hline Constant & $\begin{array}{l}12.5 * * * \\
(1.00)\end{array}$ & $\begin{array}{l}12.8 * * * \\
(1.10)\end{array}$ & $\begin{array}{c}12.7 * * * \\
(2.14)\end{array}$ \\
\hline Observations & 146 & 68 & 78 \\
\hline Provinces & 30 & 14 & 16 \\
\hline \multicolumn{4}{|l|}{ R-squared } \\
\hline within & 0.26 & 0.53 & 0.22 \\
\hline between & 0.12 & 0.01 & 0.03 \\
\hline overall & 0.11 & 0.01 & 0.03 \\
\hline
\end{tabular}

